\title{
IMPERFECT ACCOMPLISHMENT: The Fo Guang Shan Short-Term Monastic Retreat and Ethical Pedagogy in Humanistic Buddhism
}

\author{
JAMES LAIDLAW \\ University of Cambridge \\ (iD) https: / / orcid.org/0000-0002-1035-4799 \\ JONATHAN MAIR \\ University of Kent \\ (D) https:/ / orcid.org/0000-0001-6176-3157
}

Imagine eight hundred people wearing identical robes, walking in perfectly aligned rows, making prostrations in unison. They are living under quasi-military discipline in a monastery, following a tightly scripted timetable, organized by age and sex into numbered units, cut off from the outside world, observing silence. These are participants in a Fo Guang Shan short-term monastic cultivation retreat. Having taken a series of vows, they have become Buddhist monastics and are being schooled in discipline and deportment, in the philosophy of Chan Buddhism, and in chanting and ritual. Just a week later, as many of them weep openly, they will ask to be relieved of their vows, citing family commitments, and return home.

This retreat offers an intense encounter with inspiring exemplars of virtuosity, in the shape of the monastics who lead the event and the great lives and attainments described in the lectures they give. But the retreat is not only a place for virtue. It is not, as it might first appear, a flight from the contingencies of the world into a place where one can perfectly realize the Buddhist values of equanimity, wisdom, and compassion. On the contrary, it is designed as an intense and sustained encounter, in the light of those values, with one's own shortcomings. 
Bodybuilders increase their strength by repeatedly bringing themselves to the point of weakness, isolating particular groups of muscles and repeatedly loading them to the point of failure in a safe environment. So, apparently paradoxically, a gym is the place where people who wish to be stronger go to encounter their weaknesses. Similarly, retreat participants are placed in an environment that provokes, in a controlled fashion, reactions, such as greed or envy, that embody the opposite of the qualities they wish to cultivate, such as compassion and toleration. Participants living together in close quarters are subject to strict and sometimes arbitrary rules, and they are often chastised, sometimes unjustly. They are told this will provoke anger. They are deprived of their smartphones and warned that this will arouse intense feelings of attachment. All the while they are continuously exhorted to notice their flighty attention, understand their weakness of will, feel ashamed (慚愧; cankui), and renew their commitment to completing the path of the Buddha (成佛道; cheng fodao) through engaging in cultivation (修養; xiuyang, 修行; xiuxing) by monitoring their external behavior and internal thoughts. Participants hope to maintain improvements in conduct when the retreat is over and continue the task of self-cultivation in their householder lives. So, while they hope that the retreat will successfully bring about changes, success is entangled with and indeed proceeds through concerted exposure to failure and imperfection.

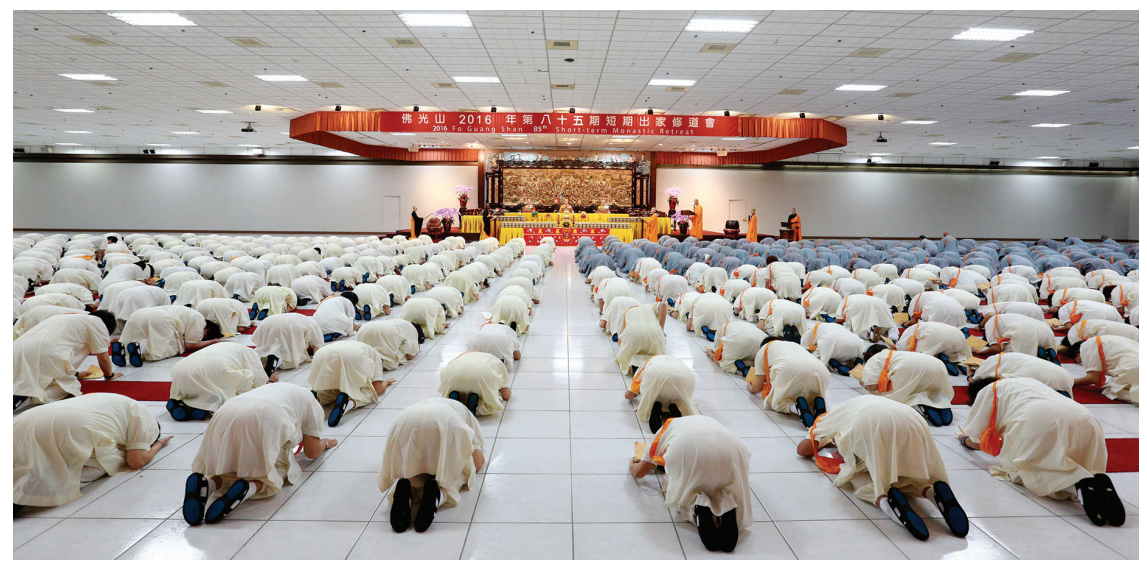

Figure 1. Preceptees prostrate in the main shrine room at Fo Guang Shan Headquarters, Kaohsiung, Taiwan, 2016. Photo by Life News Agency.

Understanding how this process works not only provides insight into this influential form of Buddhism but also proves instructive for anthropologists seeking to understand the ways in which people strive to live well — that is, ethics, broadly understood. Over the past couple of decades, many anthropologists have come to 
see ethics as happening in two modes: a transcendent mode, based on perfect values, often arbitrated by religious authorities, and an everyday or ordinary mode, based on an egalitarian, interpersonal encounter with the imperfections of embodied human life. As we discuss below, this contrast has begun to be questioned in some recent work that focuses on the ways in which, unsurprisingly perhaps, religious people routinely encounter failure. The fact that planned encounters with imperfection form the core of Fo Guang Shan ethical pedagogy calls for a still more radical rethinking of the opposition.

\section{FO GUANG SHAN AND HUMANISTIC BUDDHISM}

Based in Taiwan but global in reach, Fo Guang Shan claims around two million registered members and more than two hundred temples in twenty-nine countries worldwide. Its founder, Venerable Master Hsingyun (1927-), grew up in Jiangsu Province in China and in the 1940s was abbot of a monastery in Nanjing, but he crossed the straits for Taiwan (along with many other religious figures) when the Communists won the Chinese Civil War. From a modest base in rural northeastern Taiwan, he steadily built a lay following. By 1968 he could found a monastery (now known as Headquarters) in the hills of southern Taiwan, including a Buddhist college for training monastics. In the 1980s and 1990s, as Taiwan's economy mushroomed and political liberalization inched forward, an expanding middle class joined Fo Guang Shan and other reformist Buddhist organizations in droves, beginning to fund them handsomely (Madsen 2007; Kuo 2008; Huang 2009). Fo Guang Shan expanded overseas, first to the United States by founding Hsi Lai temple near Los Angeles in 1988, and then across Asia, Europe, and beyond. In the past ten years, it has made inroads into China, and is the only organization permitted to function as a religious institution that is not subject to direct control by the Chinese Communist Party.

Master Hsingyun describes his teachings as Humanistic Buddhism (人間佛 教; renjian fojiao). This term (originally 人生佛教; rensheng fojiao; Buddhism for human life) was coined by the early twentieth-century Chinese Buddhist reformer Master Taixu, then carried to Taiwan during the Civil War (Jones 1999, 111), and adopted there by a number of influential Buddhist leaders. Taixu thought Chinese Buddhism had become fixated on death and future lives. Monks would isolate themselves in mountaintop monasteries; lay people would sponsor services to feed hungry ghosts. He proposed that Buddhism ought to be in touch with rather than seeking to escape society, and to welcome advances brought by modernity. 
In Master Hsingyun's distinctive interpretation, Buddhism is endlessly adaptable, compatible with technology, democracy, the market economy, and liberal social ethics, as well as able to flourish in varied cultural settings (Chandler 2004). Yet, much as with many other religious reform movements, this adaptability is combined with the idea of going back to fundamentals. Self-conscious innovations are explained as reversions to Buddha's "original intent" (Hsingyun 2016) and to the underlying meaning of Chinese cultural traditions. Faithful adherence to tradition is effortlessly but self-consciously combined with use of modern technology. Participants are told that the clothing worn in the retreat, for instance, is modeled on Han Dynasty (206 BC-AD 220) styles and that the liturgy authentically follows ancient practices. Yet modernization is also pervasive and much remarked upon. Lectures and ceremony display conspicuous technological sophistication; both make liberal use of audiovisual technology. The whole retreat, for instance, is comprehensively filmed and photographed. Participants' monastic dress is completed by a plastic lanyard showing name and details, as might be seen at any modern conference.

Fo Guang Shan comprises an integrated hierarchy of male (around 300 in number) and female (around 1,400) monastics, known as fashi (法師; Dharma masters) and addressed as shifu (師父; master or venerable). They are posted for tours of duty to branch temples around the world, but all attend an annual gathering in Taiwan. Headquarters exerts considerable influence everywhere, although branches in different countries are also encouraged to develop adaptations to enable the appeal of Humanistic Buddhism to cross cultural boundaries (Mair 2014). The lay Buddha's Light International Association (BLIA) engages in charitable, educational, and cultural activities. This association and the monastics are said to be like "two wings of a bird," but ultimate authority, both moral and organizational, rests with the monastic hierarchy.

Our interest in Fo Guang Shan arose from its explicit concern with ethics, especially its intense focus on cultivation, and its creativity in adapting monastic practice for its lay following. We began a pilot project in the London temple in 2010, and have participated in activities at various temples, first interviewing leaders in Taiwan in 2014. During a discussion of concepts of the good life, Venerable Tzujong, one of Hsingyun's earliest disciples, suggested that to understand $\mathrm{Hu}-$ manistic Buddhist ethics, we ought to study the short-term monastic cultivation retreat - adding that to study it thoroughly, we needed to participate. In summer 2016, we joined the retreat at Headquarters and interviewed participants in Taiwan. In 2017, we interviewed a number of former participants in Singapore 
and Malaysia. In summer 2018, we joined the European version of the retreat, in France.

\section{ETHICS, “ETHICS,” AND “BUDDHIST ETHICS”: Disambiguation}

There are at least two ways in which a reader might be confused by our use of ethics, so let us explain what we mean by the term. The first potential confusion arises because it is often used differently in ordinary English; the second because it is used differently in Buddhist studies.

In common and academic usage in English and many other languages, ethics and morality have come to be interpreted very narrowly, as referring to codes and rules governed by a special form of obligation putatively uncontaminated by desire or self-interest. Considerations that have been very important historically and cross-culturally to questions of how to live well have been systematically excluded from this narrow version of ethics, which the philosopher Bernard Williams (1985, 174-96) dubbed "the morality system" (see also Laidlaw 2002, 2014, 110-19). An important strand of the recent anthropology of ethics has sought to make those wider considerations available for ethnographic study by expanding our understanding of the ethical.

One important way of doing this is focusing on projects of self-cultivation or autopoiesis (Faubion 2011; Laidlaw 2014). Michel Foucault's (1997) writings on ethics have proven influential, as have Aristotelian and neo-Aristotelian virtue ethics (Mattingly 2012). The emphasis on what Foucault called "techniques of the self," and on the freedom and reflection on which they depend, has sometimes been taken to refer to self-regarding rather than other-regarding behavior, but in fact both Foucault and anthropologists following him have been at pains to emphasize that projects of self-making depend on historically specific social relationships, not least pedagogical ones. An emphasis on ethics in this broad sense includes matters that go far beyond conformity or otherwise narrowly moral obligations or rules: models or exemplars that people aspire to emulate, the work they engage in to transform themselves, the relationships such work depends on, and so on.

Fo Guang Shan practice clearly constitutes an ethical project in this sense. In this tradition, human beings should improve themselves through cultivation, there exist a wide range of techniques for doing that, and Buddhism provides a particularly effective set of such techniques. Cultivation refers to a central idea in Chinese Confucian (Ivanhoe 2000), Maoist (Lynteris 2013), post-Maoist (Kipnis 2006), and Buddhist ethics: that the human being is malleable and can be transformed through practice. For Fo Guang Shan, cultivation includes developing good 


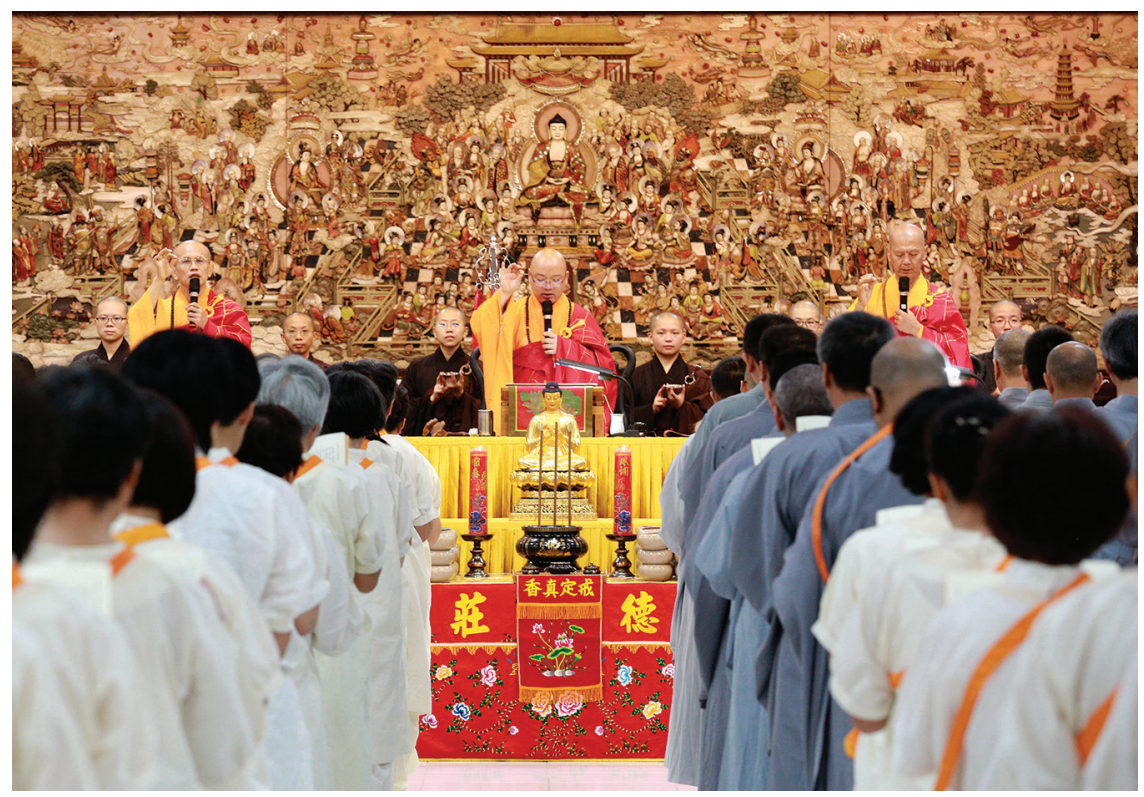

Figure 2. The witnessing master welcomes new preceptees at the conferring the precepts ritual in the main shrine room, Fo Guang Shan Headquarters, 2016. Photo by Life News Agency.

posture or learning to appreciate tea, and these things are absolutely of a piece with learning to live harmoniously with other people. This may surprise people used to speaking about ethics in the restricted sense of the morality system, just as it is surprising to read in the Nicomachean Ethics that a quick wit is as much a virtue as courage or generosity.

The second possible source of misunderstanding is that ethics is also a term of art in Buddhist studies, where it is often used to translate the Sanskrit śila (and its equivalents in other languages). Fo Guang Shan does have a concept that corresponds in part to śila, which is 戒 (jie, or 戒律; jielü). This refers to formal vows that one takes in order to cultivate, such as those taken by monastics at ordination, or vows taken by laypeople such as those known as the Five Precepts. For Fo Guang Shan, ethics in the broad sense of how to live well centrally involves self-cultivation, and so vows of this kind constitute an important ethical technology. But contrary to what is implied by those in Buddhist studies who translate śila or 戒 (jie) as "Buddhist ethics," this concept does not exhaust Fo Guang Shan's ways of thinking about how to live well, such that other kinds of excellence might be distinguished as nonethical. It is not only the taking of the Precepts in the retreat that is ethical; so is all of the trial and error involved in attempting to fulfill them. Fo Guang Shan teachings deny any clear distinction between instrumental 
action aimed at achieving goals desired by a self and ethical action aimed at benefiting others. In this way of thinking, a mistake or shortcoming in one's conduct is as much an ethical failing as is telling a lie.

\section{THE SHORT-TERM MONASTIC CULTIVATION RETREAT}

The first retreat was held at Headquarters in 1988. Fo Guang Shan sources explain that the aim was to learn from the Theravada (Southern Buddhist) practice of temporary ordination, though there are also indications that the idea was influenced by Christian models (Yao and Gombrich 2017). It was a radical innovation, but instantly successful. The three courses organized that year were oversubscribed, with three thousand applications for one thousand places on three retreats (Hsingyun 2016, 25). Fo Guang Shan uses the English term retreat, and we use it here too, although its connotations are different from those of the Chinese name (短期出家修道會; duanqi chujia xiudao hui), which literally means "short-term renunciation (leaving home) cultivation gathering."

The retreat is one of many events Fo Guang Shan runs at its temples. Some are clearly religious activities, but many are less obviously so, such as competitions for singing or debating, calligraphy classes, or tea ceremonies. These are all explicitly presented as opportunities for cultivation. The retreat is typical in this respect, but whereas other activities emphasize approachability, comfort, and convenience, the retreat is famously challenging.

It now runs regularly at a number of centers around the world. The ratio of women to men seems generally to be about four to one. In Taiwan, of eight hundred participants, all hailed from eastern Asia. In France, branch temples from across Europe sent members, both long-term local residents, mainly Cantonese-speaking first- or second-generation migrants, and students from Asia studying in Europe. At both retreats, the overwhelming majority of participants were ethnic Chinese. All activities were carried out in Mandarin, but a simultaneous interpretation of plenary sessions was provided, in languages including English and Cantonese.

Of the retreat's seven days, the first three are a struggle: disorientating and exhausting even for those who have participated before. The following days are modeled on routine monastic life for a novice: a framework of morning and evening chanting, meditation, formal meals, chores to contribute to the maintenance of the monastery, and Dharma talks and study sessions in which participants extend and deepen their knowledge of Buddhism to inform their personal practice. Almost everyone describes their experience during this middle period in terms of peacefulness, contentment, and "Dharma joy" (法喜; faxi), but as the end of the 
retreat approaches, this feeling becomes overlaid with a gathering sense that one could have done more with the opportunity, as well as apprehension and regret (mixed with an expectation of relief at release from the retreat's many challenges) at the prospect of renouncing one's vows. And then during the last hours, the generally somber mood gives way to tearful emotion.

\section{INDUCTION}

By lunchtime on the first day, participants have arrived, registered, and moved into their dormitories. They pay a modest fee (and many also make voluntary donations), ${ }^{1}$ and they receive an information pack and clothes. Men receive two pairs of cotton trousers, two long cotton tunics (中掛; zhonggua), and two sets of thick cotton stockings, worn with garters. Each participant also receives an apron and sleeve coverings for chores, and a set of more sacred items. The first of these is the haiqing (海青), a high-collared, ankle-length, gray-blue tunic with capacious sleeves that serve as pockets. The haiqing is worn at all times outside one's dormitory except for physical work and walking meditation, and it must be removed and folded correctly before entering a bathroom. Then there is the ju (具), a colored cloth used as a liturgical sitting mat, and a small bag with a shoulder strap used for carrying an alms bowl. Men receive a jiasha (袈裟), a long

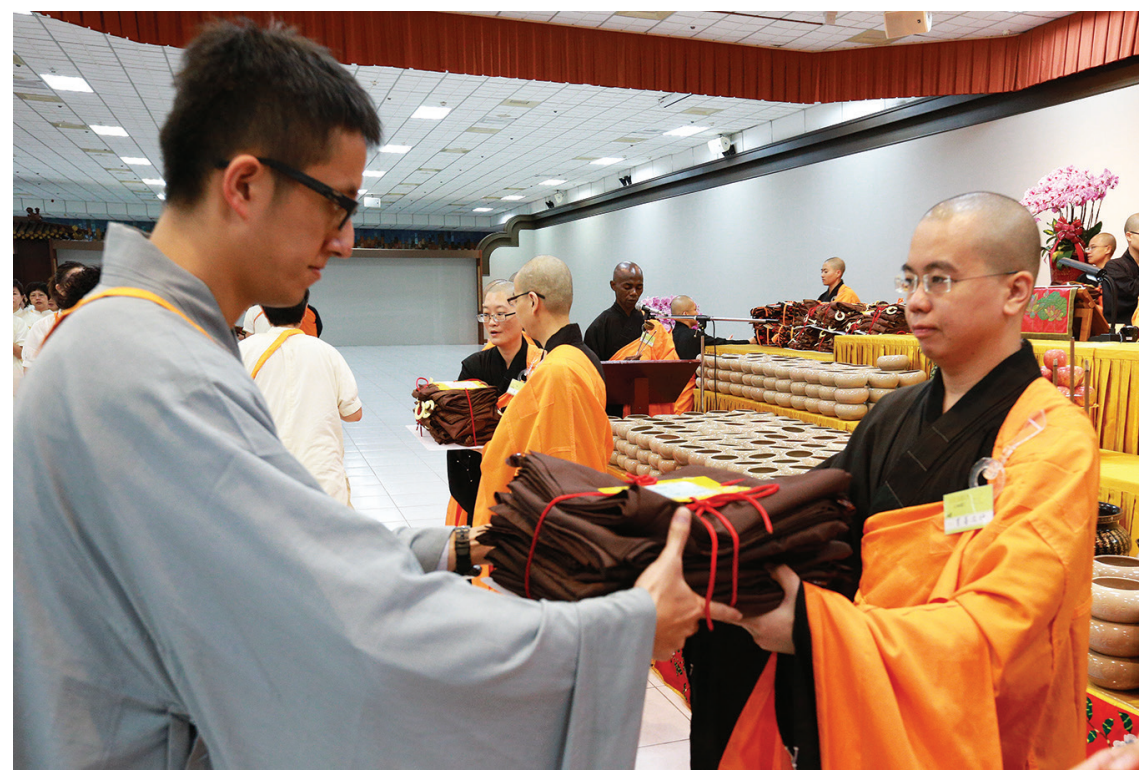

Figure 3. New preceptees are given robes, alms bowls, and sitting mats at the conferring the precepts ritual, Fo Guang Shan Headquarters, 2016. Photo by Life News Agency. 
rectangular brown cloth worn as an outer robe for most activities after initiation. Women take different vows and their clothing differs accordingly: a knee-length, short-sleeved, cream-colored tunic, and, in place of the jiasha, a shorter, sleeveless brown tunic (式叉摩那服; shichamonafu).

Participants are assigned dormitories by group, and these groups are essential to the basic mechanics of the retreat. Each participant's lanyard shows the group (堂; tang) and the half of that group (班; ban) to which they belong, as well as their numbered position (號; hao) within it. Each ban has a leader (班長; banzhang), usually someone who has attended a retreat before, who walks first in line and exercises some delegated authority on behalf of the monastics. Before and after all activities, each group lines up in order for inspection. Throughout the week participants will sleep, dress, walk, sit, stand, kneel, chant, prostrate, meditate, eat, and work, alongside these neighbors. When they have unpacked the few things they are allowed to bring - underwear, minimal toiletries, one pair of shoesthey deposit the rest of their luggage and valuables (including electronic devices) for safekeeping.

Then training begins. A video covers the history and purpose of the retreat, demonstrates correct ways to bow, and correct procedure at meals. An orientation speech sets out basic parameters: "Maintain silence. You may not leave the monastery precincts, and within them, go only where specifically instructed. In particular, do not enter anyone else's dormitory or contact any friends or relations you may have here. When waiting for activities to begin, do not look about you or let your mind wander, but use the time memorizing the texts used in liturgy." Two senior monastics, the master of ceremonies (開堂和尚; kaitang heshang) and the discipline master (糾察師父; jiucha shifu), begin what will become a constant chorus of admonishment: "You will make mistakes and will need to be corrected. You need to receive criticism and correction in a spirit of humble gratitude. A grateful heart is soft, and only if you have such a heart can we teach you the path." The intensely (albeit silently) social nature of the retreat is emphasized: "When you live with a group, you cannot help but compare and compete. This will generate feelings of grasping. "Why am I not as good as the other person? Why am I so unlucky?' These feelings will come and torture you." From now on, everything that is done, the way participants stand, sit, eat, and walk, is subject to minute instruction, intensive practice, and relentless correction by these and other monastics, especially the guiding venerable (引禮法師; yinli fashi) appointed to oversee each group. 


\section{BECOMING A MONASTIC}

Groups intensively practice dressing and undressing, folding sitting mats, standing, walking, and bowing correctly. And there are rehearsals for the main ceremonies to come. Fo Guang Shan rituals are meant to be solemn (莊嚴; zhuangyan). Movements are carefully choreographed. Participants are encouraged to memorize key texts such as Inviting the Holy, the Heart Sutra, and the Dharani of Great Compassion. Four ceremonies are required to make monastics out of the participants. Each takes between one and two hours to rehearse and then about as long to perform.

The first ceremony, at the end of the first day, is purification (灑淨; sajing). The entire space in which the retreat occurs is ritually cleansed and sealed. The Buddhas, Bodhisattvas, and spirits are invited, with flowers and incense, to witness the proceedings. The space, and all the participants, are sprinkled with holy water.

By the time participants retire to their dormitories after purification, a general mood of shell-shocked disorientation has taken hold. They are dressed in unfamiliar clothes and unsure how to behave; almost anything might turn out to be a mistake and subject to sharp correction. They are sharing this experience, living in close quarters with people they have probably never met before, about whom they know almost nothing, and with whom they are not allowed to converse. There is a strict lights-out time shortly after the end of the ceremony. Although most people return drenched in sweat from the many prostrations, they are not allowed to bathe and are required to sleep still wearing their tunic and trousers. Hot, tired, and uncomfortable, reeling from a sustained fusillade of prescriptions and prohibitions, abruptly cut off from responsibilities and loved ones, participants find that the required silence makes anxieties about life inside and outside the retreat echo all the louder in their minds.

The second day begins with the second grand ritual, the ordination ceremony (正授; zhengshou). While the assembly recites praise of the incense offering, a small delegation processes out of the hall and invites a witnessing master (a senior monastic) to come to perform the ceremony. He prostrates before the Buddha, invokes the Buddhas and spirits as witnesses, and reads a discourse on the merits of renunciation. At the end of the rite, as the witnessing master leaves, the ordinands make a gesture of respect, and he calls out a series of encouraging instructions_- "Think of your causes and conditions!" "Cultivate diligently!" - to each of which they reply loudly: Amituofo! (阿彌陀佛!; Amitabha Buddha!). 
Returning to their dormitories before breakfast, ordinands are issued with a new monastic name, which is used from now on and replaces their lay name on their lanyards. This day continues with more training and rehearsal, as well as lectures on the meaning of the Precepts, and ends with a lengthy rite of repentance, with many prostrations that leave ordinands sweating and exhausted but spiritually ready on the third morning for the last of the four opening ceremonies, conferring the Precepts (傳受戒; chuanshoujie).

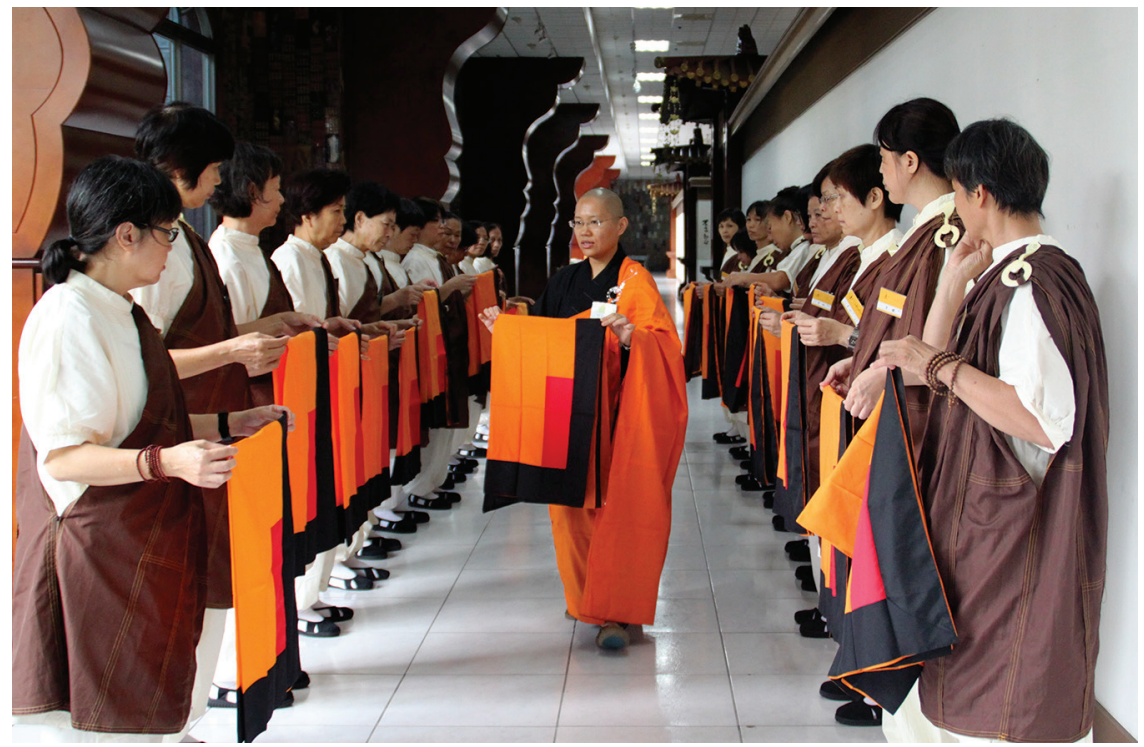

Figure 4. A guiding venerable shows a class of new preceptees how to fold the sitting mat, Fo Guang Shan Headquarters, 2016. Photo by Life News Agency.

Kneeling and dressed in their haiqing robes, they take their monastic vows, six for women (do not: act licentiously, steal, kill, lie, eat at forbidden times, or take intoxicants) and ten for men (refrain from: killing, taking what is not given; sexual activity; incorrect speech; intoxicating drinks or drugs; eating at forbidden times; dancing, singing, and so on; wearing ornaments; using a luxurious bed; and accepting money). The women's vows are different, we are told, because an old rule stipulates that men may ordain as monastics up to seven times in one lifetime, while women may ordain only once. If women were to take full monastic ordination temporarily, it would be impossible for them later to ordain permanently. So, they take precepts that are short of full ordination (the 式叉摩那戒; shichamounajie or śikșamānā precepts). Men take the full novice precepts (沙彌戒; shamijie or śrämanera precepts). However, the difference is never explained during the re- 
treat and the importance of the distinction is played down; all participants are told to remember they are now "real renouncers" (真的出家人; zhende chujiaren).

At the culmination of this ritual, the markers of a Buddhist monastic - robe, sitting mat, and alms bowl_ - are conferred. As ordinands put on their monastic robe in the manner they have been practicing, they chant, "Wondrous robe of liberation, unequaled field of merit. Today I put it on. Life after life, I will not remove it or be distant from it.” The participants are now monastics and referred to as preceptees (新戒; xinjie).

This ceremony marks the most physically demanding part of the retreat. Just how demanding varies between venues, with Headquarters in Taiwan having the justified reputation for being the most severe, including the most complex ceremonial and long periods of painful kneeling on a hard floor. The emotion elicited is very marked. But with the ceremony's completion, participants have reached a turning point. The intensity of the timetable is reduced, exhortations from the monastics begin to include occasional praise as well as relentless criticism, and many preceptees experience much calmer mental states, progressively letting go of extraneous concerns and finding a greater capacity to concentrate on their cultivation. This was also our own experience. But as preceptees become more skilled, monastics become more demanding, issuing instructions such as "Follow the lines in the paving when processing, but don't look down" and "Don't just finish your food, but use a piece of vegetable to clean the last drop of the sauce from your bowl, without making noise.”

\section{LIVING THE LIFE OF A MONASTIC: External and Internal}

\section{Monitoring}

From now on the daily schedule is less punishing, but still every minute is accounted for, from the sounding of the wooden board that signals wake-up (5 a.m. in Taiwan, an hour later in Europe) until lights-out (10-10:30 p.m.). The day is taken up with morning and evening chanting, formal meals, lectures or Dharma talks, diary writing, chores around the monastery, and the business of keeping bodies, clothing, and dormitories clean.

All these activities, no less than the grand ritual dramas, explicitly constitute opportunities for the practice of cultivation through constant monitoring and correction. Preceptees are enjoined to concentrate (專心; zhuanxin or 用心; yongxin). Maintaining silence is crucial. As one monastic observed: "If you observe silence for seven days, you will find something different about yourself. You will be able to hear your mind. Don't communicate with each other, even silently. Some people 
are trying to connect by Wi-Fi. What does that mean? Eye contact! Be silent, and you can calm your mind and listen to it. When you calm your mind, impurities will sink to the bottom." In lectures and ongoing instruction we were told to maintain two kinds of concentration: external monitoring (外觀; wai guan), focusing on the body, movement, and use of space; and internal monitoring (内觀; nei guan), the observation of one's heart (心; xin). It is important to understand that this distinction does not correspond to the distinction that anthropologists have often made between the individual and the social. On the contrary, since both are realized in coordinated and cooperative interaction, both external and internal monitoring integrate the cultivation of self and other in a single process.

External monitoring is mainly concerned with what Fo Guang Shan monastics in English call "etiquette” (in Chinese, 威儀; weiyi, which means "majestic presence" or "impressive manner"). This essentially consists of a radical intensification, achieved by thoroughgoing ritualization, of Fo Guang Shan's general concerns with respectfulness, politeness, and beauty. The rules of the retreat make these concerns, applied to everything from mundane dormitory life to collective ceremonies, all-encompassing.

The core of etiquette is deportment, the importance of which is signaled by the fact that its components — walking, standing, sitting, and lying down in prescribed fashion — are referred to as the Four Great Comportments (四威儀; si weiyi). When walking, for instance, gait should be smooth, posture upright, with eyes slightly lowered. Hands should be loosely clasped, fingers in a prescribed configuration. When sitting, one should have a straight back, without leaning on the back of the chair. Individual lapses, whether during study sessions, lectures, meals, or ceremonies, are corrected with a sharp look or word or a tap on the shoulder from behind.

A key setting for concentration and etiquette is dining (過堂; guotang; “passing through the hall”). Preceptees enter the dining hall in formation, silently file to their places, bow in unison, and take their seats. The food is all vegetarian, although it often includes dishes cunningly disguised as meat. Every movement is prescribed: how to pick up the chopsticks, lift each plate and bowl to new positions, hold a bowl while eating from it (the "dragon holding a pearl" position), use chopsticks (the "phoenix nodding its head" movement), and place bowls to indicate a request for more food. Servers pass silently but speedily along the rows, serving more food to those who signal for it.

Maintaining beautiful deportment is not easy. Monastic clothes, especially the men's, are so designed that without constant attention and adjustment they 
will slip from the correct position. For example, the end of men's long outer robe must be folded thrice and looped over the left arm so that it hangs down to the correct length, forming a tidy pleat. One's left arm therefore needs to be kept bent more or less at a right angle, with about four-fifths of the robe's length on the outside and only a fifth on the inside. If not checked and corrected regularly, it will slip from position. In the same way, dining with proper etiquette is a fraught process. The chairs must be moved with care to avoid making a noise. The metal chopsticks, placed at the near edge of the table, are easily knocked off by uncontrolled robes or by the lanyard dangling from preceptees' necks as they try to sit down silently, and sent tinkling loudly to the floor. The cause of errorswardrobe failures, wayward chopsticks, dropped food-as venerables never tire of reminding preceptees, is a wandering mind. The exhortation following each such mistake is an embarrassing reminder for the culprit and everyone else to focus on cultivation.

Internal monitoring means focusing on the mind to identify and try to remove afflictions (煩惱; fannao), especially greed (執著; zhizhuo) and the spirit of comparison (比較; bijiao). Monastics frequently emphasize that this internal renunciation with the mind (心出家; xin chujia) is as important as the external renunciation with the body (身出家; shen chujia). They are causally linked because

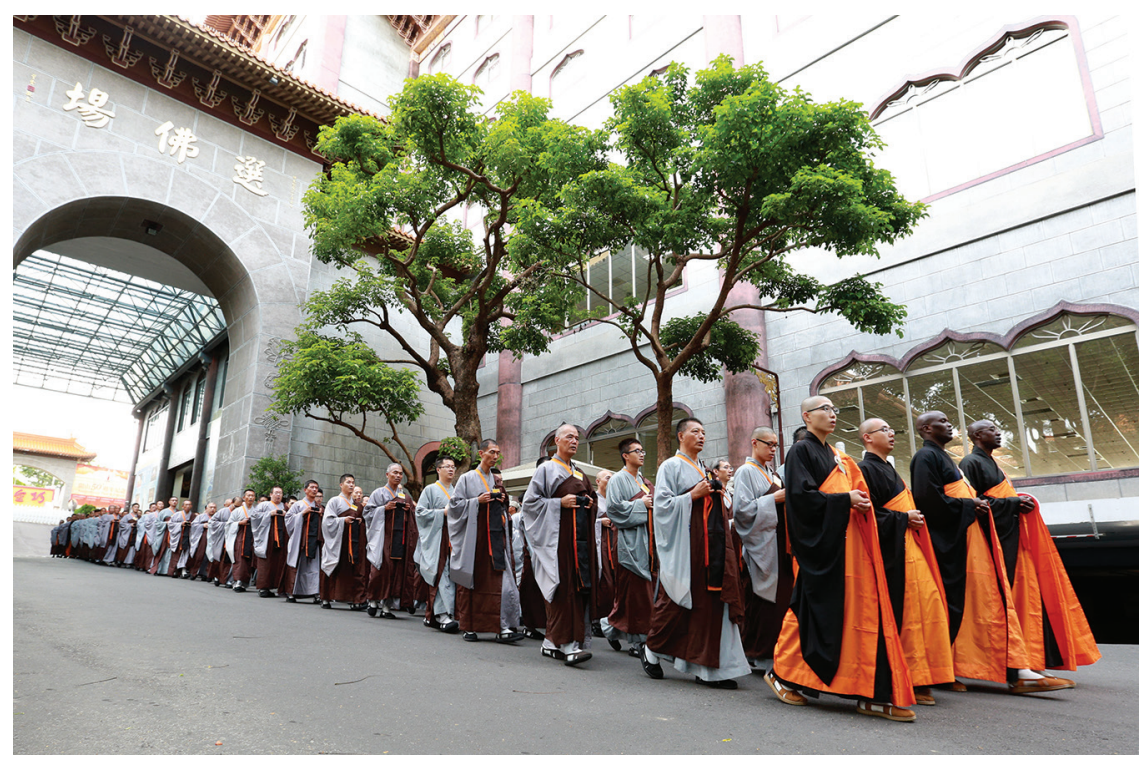

Figure 5. Preceptees walk in formation behind their guiding venerables. They are wearing the jiasha robe, holding the sitting mat before them, and carrying the alms bowl in a bag worn over the shoulder. Fo Guang Shan Headquarters, 2016. Photo by Life News Agency. 
"the human heart tends to follow outer impressions and has no way to govern itself, for that reason choosing a pure environment can produce a real benefit in terms of our frame of mind" (Fo Guang Shan n.d.).

Throughout the retreat, participants are told which thoughts or feelings they ought to cultivate and avoid. For instance, specific thoughts are prescribed for chores. Groups of preceptees are given tasks such as weeding, sweeping, serving at meals, and cleaning lavatories. They are told to remember that self-cultivation is like this endless work, requiring qualities of endurance and diligence. An interviewee reflected: "In the lawn there were lots of weeds. I imagined that I was plucking my mental troubles. Our minds are cluttered with unnecessary stuff. We should pluck out these weeds that are cluttering us and taking our nutrients."

While dining, preceptees should concentrate on the Five Contemplations:

1. Ponder the effort necessary to supply the food, and appreciate these origins;

2. Reflect on one's own virtues, and consider whether they are sufficient to deserve this offering from the faithful;

3. Guard one's mind against faults, especially avoid being greedy, and refrain from selecting by preference among the foods on offer;

4. Consider the food as medicine and nourishment, to prevent emaciation of the body;

5. Receive the food as necessary to sustain oneself for spiritual cultivation.

These contemplations plainly seek to ensure that preceptees' internal monitoring seamlessly links the social conditions and relations in which their activity is embedded — and which are the material precondition for their practice - with their bodily and mental experience, just as the rules of the practice itself ensure that their external monitoring is a tightly coordinated process of social interaction requiring the minute regulation of bodily deportment.

\section{SELF AND OTHER}

Opportunities for internal monitoring arise continually in relation to other people. Although the work of self-cultivation requires individual effort, the form of life that sustains it is intensely collective and systematically ensures that preceptees have to confront a range of challenging feelings.

Participants' backgrounds vary widely. They rarely know each other, and the requirement for silence means that they cannot get acquainted in a normal way. 
Dormitories are packed. There are precise rules governing exactly how and where bedclothes, spare clothing, toiletries, and books must be placed. Little time is allowed for dressing and tidying in the morning, for bathing and laundry in the afternoon, and for retiring at night. Everything must be done in a rush, resulting in a distinctive atmosphere of frenetic but silent activity. The dormitories are periodically inspected, and demerit points awarded for each misaligned tooth mug or imperfectly folded duvet. The justice dispensed is rough, and venerables make a point of the fact, urging preceptees to overcome the moral emotions aroused by it: "Don't complain that you earned a cross because someone else moved your towel after you had folded it. Why should you be disturbed by what is fair and unfair? Just accept gratefully and focus on keeping the right attitude and concentration. Make sure you do it correctly in future.”

Much of what groups have to do requires precise coordination. They must assemble for inspection at appointed times and frequently need to bow, kneel, prostrate, stand, and speak in unison. Walking from place to place is generally done in perfectly aligned pairs of columns, maintaining formation through sharp right-angle turns, and gathering robes correctly and adjusting pace for climbing or coming down stairs. However careful you might be, if the person in front of you goes out of line, there is literally no longer a correct place for you to be.

It is therefore easy to become frustrated with one's companions and hard not to compare oneself with neighbors and find oneself either wanting or superior. Venerables draw attention to this and insist that preceptees should feel positively toward those who might annoy them: "They are giving you the opportunity to cultivate, so you should think, 'thank you, pusa [菩薩; Bodhisattva].” A sense of group responsibility is also encouraged. Guiding venerables make clear that if their group is late, or badly turned out, or deficient in etiquette, they will in turn be criticized by more senior monastics. Yet we were struck by the toleration of those whose mistakes caused problems for their group.

The slowest and most error-prone are gently encouraged and corrected, with at most wry amusement. Quite rapidly a warm, uncompetitive solidarity develops, with a silent intimacy and sense of shared achievement in the face of adversity. A day or two into the retreat, on both occasions we participated, we found preceptees straightening incorrect folds in their neighbors' robes, checking that each other's lanyards were hanging correctly, and silently sharing tips about how to get prayer books in and out of haiqing sleeves smoothly. In this highly ritualized practice, what promotes such solidarity is not so much, as a Durkheimian approach 
might lead one to expect, direct experience, effervescent or otherwise, of anything transcendent, but a sustained and shared struggle with imperfection.

The lessons to be drawn from individuals' mistakes are transmitted to the whole retreat during meals and lectures, with presiding venerables recounting, "One person did such and such, and the reasons why this is wrong are thus and so. You should all avoid this mistake.” Such public criticism is always anonymized, and the correction of individuals, while sharp and direct, is also done discreetly; if verbalized, it is usually directed at a whole group. Further discreet correction is provided by each group's guiding venerable in written feedback on the daily diaries participants are required to write, recording their thoughts and feelings.

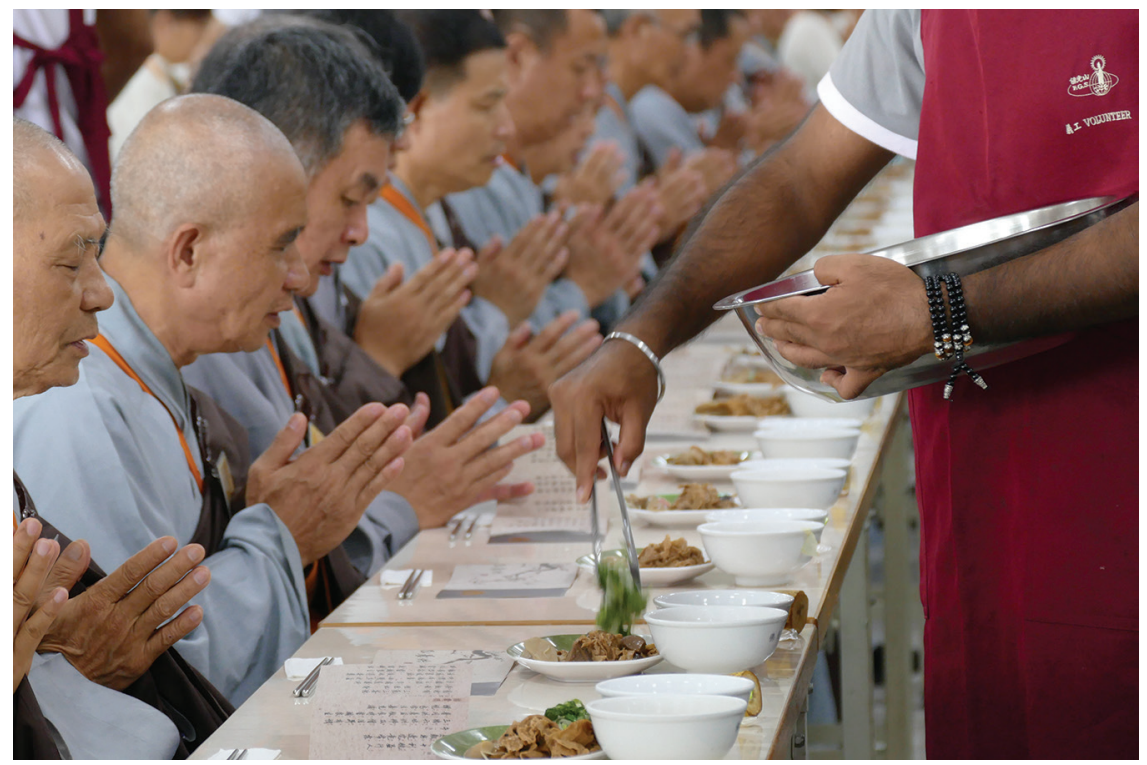

Figure 6. Preceptees eat together during the retreat at Fo Guang Shan Headquarters, 2016. Photo by Life News Agency.

Tellingly, prominent among the mistakes that venerables most eagerly discourage are enthusiastic attempts to excel or exceed prescribed requirements: preceptees who do extra prostrations at night, for example. This is denounced not only because it disturbs others' sleep but also because the motivation is suspect. A few preceptees choose to follow strict monastic practice by not eating at all in the evening. This is permitted, but they are required to attend the dining hall with everyone else, be served food, and sit in contemplation while the rest of the assembly eats. In a lecture during the European retreat, a senior venerable explained the thinking: 
Once an opera singer came to the London temple and challenged us by singing very high, and then very low. In the end she was defeated by us. She realized we are connected to the Buddha. If you have a great voice, you might want to show off, but you will be defeated by the congregation. ... We are all trained in the same way, so we sing in unison and it sounds very good. We have the power of community. Practicing on your own is dangerous; doing it in a group is better. Our water and land ceremony has 108 monastics singing, but we are not there to compete with each other. It's all about teamwork. This is important for cultivation: you need other people around you or you won't know that you've changed.

This last point recalled, for us, a central idea from Adam Smith's (1976) Theory of Moral Sentiments about the irreducibly social nature of ethical life.

\section{PERFECTION, IMPERFECTION, TRANSCENDENCE, AND THE EVERYDAY}

The retreat's combination of intensive self-reflection and relationships based on care and intimacy is hard to square with the analytical distinction, which has become established in the anthropology of ethics, between two modes of being and acting: a transcendent mode, in which people reflect on otherworldly values, mediated by ritual and the (typically) religious authorities that control it, and an everyday or ordinary mode characterized by caring accommodation for others amid the unpredictable messiness of embodied human life. This distinction has become the basis of debates as writers have adduced ethnographic examples to argue that ethical life is dependent on one, but not really on the other mode. Where have these debates come from?

One formative aspect of the anthropology of ethics was attempts to take seriously values and projects at odds with those of most readers of academic anthropology, often for convenience referred to as nonliberal. Authors writing in this vein (Asad 1993; Laidlaw 1995; Robbins 2004; Mahmood 2005; Hirschkind 2006; Cook 2010; Faubion 2013) sought to convey the integrity of these forms of life, resisting the temptation to see them entirely through the lens of progressive politics (a similar effort characterized the emerging anthropology of Christianity; see Harding 1991). In particular, they challenged the idea that freedom necessarily requires resisting authoritative norms, arguing that it might equally consist in actively inhabiting them. And they maintained that anthropology should not be preemptively committed to one model of human flourishing but take seriously as 
diverse forms of ethical life even ideals and values widely disparaged in contemporary academic circles, for instance as regressive, repressive, or patriarchal.

These studies, including those of Islamic piety movements by Talal Asad, Saba Mahmood, and Charles Hirschkind, proved deservedly influential, but critics argued that they privileged religion in general and single-mindedly religious people in particular, and that they described what successful progress in regimes of self-cultivation looked like at the expense of conveying the complex and sometimes conflictual experiences of people actually pursuing those projects (e.g., Marsden 2005; Schielke 2009; Simon 2009; Mittermaier 2012; Laidlaw 2014; Keane 2016).

One response to these perceived failings has been to assert the importance of ethics in the ordinary or everyday (these terms being routinely used interchangeably), including outside formal religious or political institutions, among people who make no conspicuous claims to extraordinary virtue. This approach has enabled some perspicuous descriptions of ethical life, in acts of care and intimate joys and sufferings, especially in modest circumstances (e.g., Das 2010; Jackson 2013; Schielke 2015; Singh 2015). However, the injunction to locate the ethical in the ordinary has often proven unhelpfully disjunctive. The implication has been not only that (usually unspecified) others have actively excluded the everyday from the scope of ethics but also that it is an error to think that the religious or the political might ever constitute important sites of ethical life. Ethics in this view might be an immanent and pervasive dimension of human life (Lambek 2010), but life construed as excluding anything that is ordered or institutionalized, specifically formal religion. Thus, Michael Lambek (2010, 2, our emphasis) influentially characterizes ordinary ethics as "relatively tacit, grounded in agreement rather than rule, in practice rather than knowledge or belief, and happening without calling attention to itself." Similarly, Veena Das $(2012,134)$ sees ethics as "a dimension of everyday life in which we are not aspiring to escape the ordinary ... not by orienting oneself to transcendental, objectively agreed-upon values."

Joel Robbins (2016) has countered that religion quite obviously provides a widespread source of morality, and that a focus on the ordinary to the exclusion of the transcendent misses the importance of religious ritual in grounding values in emotion (see also Lempert 2013; Clarke 2014). Rituals have this effect, he argues, because they enable people to experience a pure manifestation of moral values, unobtainable in other settings: Christian rituals among the Urapmin of Papua New Guinea, for example, provide the only settings in which their paramount value of lawfulness is fully experienced. One such ritual ends in an emotional levity, which Robbins (2016, 779) interprets as Durkheimian effervescence, which "is precisely 
what it feels like to realize a value fully - to realize something transcendent in its transcendent form, rather than in the piecemeal, often compromised forms in which one realizes values, if one realizes them at all, in ordinary life." Thus, while persuasively opposing Das's and Lambek's claims that religion, ritual, and the transcendent do not constitute a real source of ethical value, Robbins develops his position within the general schema on which their position is based: a distinction between a perfectly ordered transcendent sphere (the domain of religion and especially ritual) and a messy everyday sphere. ${ }^{2}$

Another line of thought that locates ethics in the ordinary or everyday emphasizes the ways in which the pursuit of "grand schemes" (Schielke and Debevec 2012), such as those advanced by religious or political institutions, are undermined by the exigencies of everyday life. Again, much of this literature assumes that religion typically requires the unflinchingly consistent, successful execution of a clear moral system, which must overcome the messiness of everyday life.

Some insightful recent studies, responding to this line of argument, have interpreted the accommodation of failure as a positive aspect of religious ethics (e.g., Fahy 2017; Mayblin and Malara 2018). In a stimulating collection on failure in Islam and Christianity, for example, Daan Beekers and David Kloos (2018, 2), while noting how much we learn from studies that highlight experiences of imperfection and incoherence in religious ethical striving, regret that "the everyday perspective" tends to place such experiences "outside the domain of religious experience 'proper." They instead examine how senses of falling short "feed back into Islamic and Christian ethical formation" (Beekers and Kloos 2018, 2). Such experiences, they argue, are often positively embraced and valued in these traditions, as a test of faith, a lesson in humility, and a spur to ethical striving. "Our specific contribution," they write, "is that we investigate the dialectical relationship between Muslims' and Christians' experiences of moral instability, fragmentation or ambivalence on the one hand, and their attempts to achieve a level of moral coherence grounded in religion on the other" (Beekers and Kloos 2018, 12). As these scholars present things, fragmentation enters moral experience when the exigencies of nonreligious life undermine the pursuit of religious order. It is something that life does to religious practice, to which the latter must find a response.

To make sense of the Fo Guang Shan retreat, we must go one step further. There, perfect ideals and imperfect practice are not opposed or in a zero-sum relation; it is not that transcendent religion coexists with and accommodates the mundane. Imperfection is not merely an opportunity religion takes to advance its program, by seeking as it were to make a virtue out of necessity. Rather, it is a tool 
actively deployed by religion itself in its most serious ethical striving. It would be mistaken, in other words, to think of experiences of falling short and the religious practice of self-cultivation as being in a dialectical relationship.

And neither is it the case, as Robbins's interpretation of ritual as transcendence might suggest, that this religiously inspired ethical pedagogy proceeds principally through an experience in ritual of perfected ideals, that is, through an (albeit fleeting) attempt to manifest the transcendent, "realizing one or a few values very fully" (Robbins 2015, 28). If that were the aim, the retreat would be constructed differently. As in much liturgical ritual, mistakes and missteps would be simply ignored, with only the successful completion of prescribed actions acknowledged as having occurred at all (Humphrey and Laidlaw 1994; Seligman et al. 2008). Instead, the conditions are such that chronic, repeated failure becomes inevitable and salient.

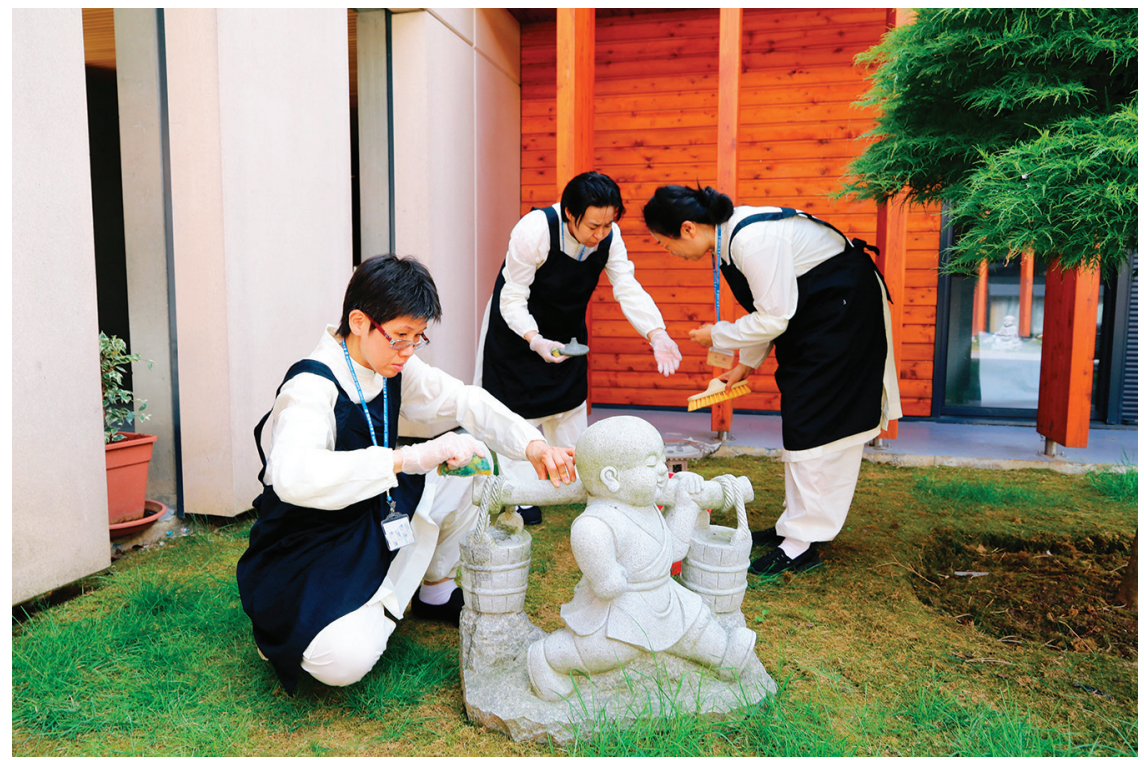

Figure 7. Preceptees carry out chores, carefully cleaning a Buddha statue and other garden ornaments at the Fo Guang Shan European Headquarters, Fahua Temple, Bussy-Saint-Georges, near Paris, 2018. Photo by Life News Agency.

This is not, for example, an environment in which it is difficult to talk. It is a place instead with endless opportunities for talking (and quite a bit does surreptitiously take place) as one lives continuously cheek by jowl with others. Likewise, it is not a situation in which it is impossible to be greedy. At every meal, participants are told they can eat as much as they want, and requesting more food is straightforward. Participants have to confront their appetite head on. The detection of 
mistakes is relentlessly pursued, with spot-check inspections of dormitories and monastics posted so as to catch incorrect posture as preceptees walk by, or while sitting. Admonishments and expressions of disappointment at preceptees' failures are among the most dramatized aspects of the whole, highly ritualized performance. Both shortcoming and its correction are scripted throughout.

Thus this exercise in ethical striving is, simultaneously, a carefully engineered encounter with the experience of inevitable ethical shortcoming. And the falling short at issue is not the intrusion of everyday contingency into religious order, but the result of following faithfully the program of activity mandated by the religious tradition itself. So, it would be incorrect to describe what the retreat aims at as "moral coherence grounded in religion" (Beekers and Kloos 2018, 12). Certainly, Humanistic Buddhism is as coherent as any ethical and philosophical system, but the ethical subjectivity it seeks to develop, in general and in the retreat in particular, does not constitute a coherent and consistent telos, which it might make sense to seek exactly to attain. It is intrinsically unrealizable (Emmet 1994): a practice to which disconcerting paradox, ambivalence, and unknowability are intrinsic, and it is conceived as a never-ending process rather than a state. Just as failing to live up to an ideal or to follow a norm does not imply that one is not nevertheless committed to it - it might even be profoundly defining of one's way of life - so the fact that an ideal is intrinsically unattainable does not prevent one from orienting one's life in relation to it (Laidlaw 1995).

\section{IMPERFECT ACCOMPLISHMENT}

The final phase of the retreat consists of a sequence of events over the final twenty-four hours: group discussions, repentance (懺悔; chanhui; in Taiwan, a challenging ceremony involving 108 full prostrations, abbreviated in Europe), a general discussion, the relinquishment ceremony, and a final exhortation. All these events are designed to elicit strong emotions, and in their Dharma talks and remarks, the venerables prepare the ground for this emotionality, remarking that time is running out ("Have you made the most of it? There is still some time. Remember your original vows"), predicting its occurrence ("Do you think you will weep?"), and using increasingly emotional language to describe their own state of mind in relation to the preceptees ("We are very sad and feel like weeping").

In the group discussions, preceptees finally have the chance to speak freely to the twenty or so people with whom they have shared a very intense and challenging experience. They are asked to say what brought them to participate and might reveal family and personal religious histories, marriage breakups, career dif- 
ficulties, or terminal illness. We were taken aback by how courageously people spoke about terrible circumstances or confessed to faults and failures. The group's guiding venerable interjects from time to time, with advice to those considering full renunciation or encouraging those undertaking the retreat in order to benefit a sick family member, to make a statement formally dedicating their merit.

In the general discussion, a selection of preceptees express gratitude before the whole assembly to the venerables, the volunteers, and their fellow preceptees, which leads to frank expressions of how moved people are to have participated, tearful accounts of afflictions in their lives and how practicing Buddhism has helped them come to terms with them, impassioned expressions of devotion to Master Hsingyun, stories of bitter personal conflicts and heartfelt vows to resolve them, and fervent resolutions to live changed lives in the future.

From this carefully choreographed emotional drama, the assembly proceeds to the main shrine for the last time. The final relinquishment ceremony is markedly downbeat. The witnessing master attends without the usual ostentatious invitation and procession. Already many of the preceptees are weeping openly. We all kneel and read a humble request to be released from our vows. We remove and fold our robes, which are gathered in quietly, followed by our sitting mats and alms bowls, without the joyful music and chanting that accompanied their distribution. As the witnessing master leaves the hall, he this time shouts no words of encouragement, but leaves in silence. One of the senior monastics comes forward and tells us mildly that this marks the end of the retreat. As many now former preceptees wipe tears from their faces, we are enjoined to take what we have learned and continue to practice as much as we can in lay life.

Official publications describe how Master Hsingyun established the retreat to allow householders to experience monastic life, to engage in cultivation, and to increase their merit so that they will afterward set an example to others, thereby contributing to social stability. Our interviews revealed a wider range of motivations among participants. Many - like the woman who wanted to learn to control her temper or the former army officer who wanted to become less domineering sought to transform themselves in specific ways. Others had taken part because their spouse insisted. Some had recently lost a parent and hoped to transfer the merit to assure them a good rebirth. Like several others, a financial worker from Singapore told us that he regretted not being able to become a monk. By participating, he had planted a seed that might result in his doing so in a future life. Younger people who have not married might yet join the monastic community on a permanent basis, and a number said they were seriously considering this, but had 
not made up their minds. Among the older participants, several had been or were still seriously ill and hoped to earn merit that would benefit their health. One man revealed that he was recovering from a tumor of the neck, which doctors had said would be fatal. He had prayed to the Buddha and promised to join a retreat if he was cured. The tumor duly shrank, and he fulfilled his vow. Others had made similar vows in pursuit of exam success or other professional goals.

Many participants claimed lasting changes in their everyday life - if not becoming fully vegetarian, then moving in that direction, or reducing alcohol consumption, or refraining from killing insects. Others reported more dramatic changes. One young Singaporean woman went home, packed four boxes of clothes and shoes to give to the Salvation Army, and quit her job with an airline. After volunteering at a temple in the Philippines for some time, she started a new career as a charity fundraiser. "Oh," she added, "and I gave up drinking coffee." Others found they were unable to sustain the self-improvement they felt during the retreat for very long afterward, and some of those used imagery of needing to be "recharged." Perhaps thinking back to the retreat and how one felt then might help? Others concluded that they had to undergo it again.

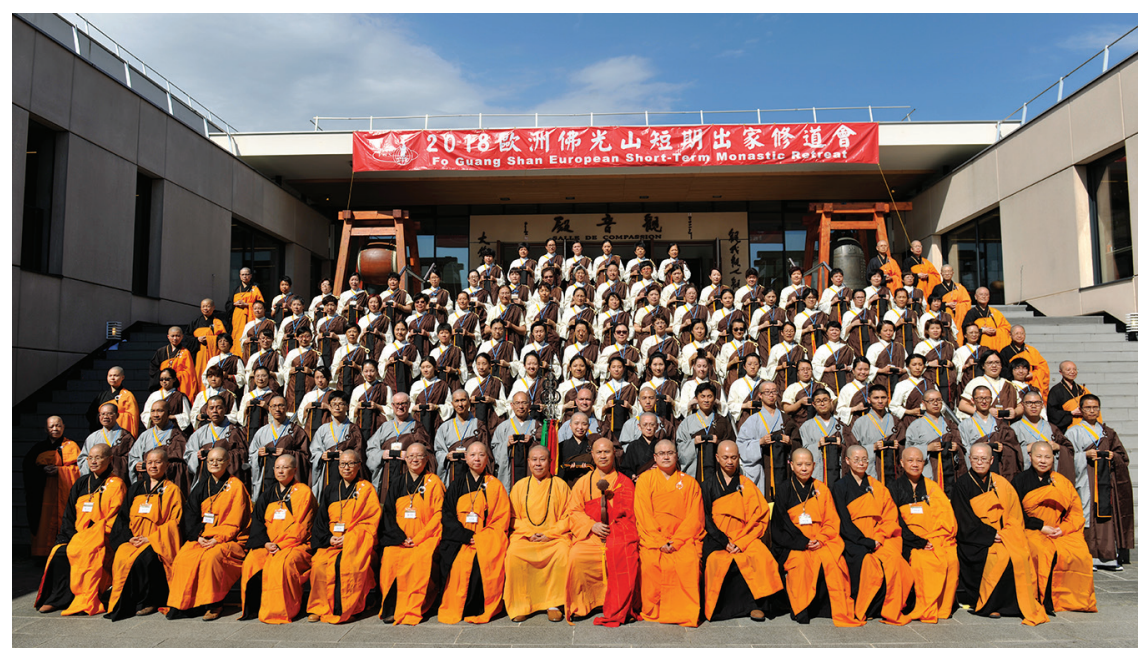

Figure 8. Preceptees and monastics pose for a group photo after the conferring the precepts ritual, Fo Guang Shan European Headquarters, 2018. Photo by Life News Agency.

Almost all these participants linked the effects of the retreat directly to the idea that it involved genuine monastic initiation, which they acknowledge as extremely challenging. The very minuteness of the regulations and the strictness with which they are enforced, the fact that there is always some criterion by which one may be found wanting, some further improvement to be aimed at, all emphasize 
how exceptional and efficacious it is. So, while preceptees may chafe under the discipline enforced on them, the value of fulfilling their vows depends directly on its unappeasable severity.

\section{CONCLUSION}

The Fo Guang Shan short-term monastic cultivation retreat is a formal, structured exercise in ethical pedagogy of a kind that is widespread in diverse religious traditions but also has close analogies in secular forms of training, treatment, and rehabilitation (Kondo 1987; Lester 2005; Cheng 2009; Cook 2010; Zigon 2011; Borneman 2015). Yet the premises that continue to underlie current anthropological debates about ethics show that little attention has been paid not only to practices of this kind but also to ethical pedagogy in general (but see Faubion 2011). The case of this retreat indicates, we suggest, that the anthropology of ethics has much to learn from such practices. It demonstrates, first of all, that ethical striving, in a religious and ritual context, is not only in practice compatible with, but in this case actually depends on, participants in some senses not being up to the task. Preceptees take vows to be pure in mind and body and loudly affirm that they can uphold them, but the whole drama ends - designed purposely to come to this conclusion - with an admission of defeat. Participants accept the robes of a monastic and promise not to take them off from one life to the next, until they have liberated all beings. Days later, they plead that family commitments prevent them from fulfilling these promises, and the witnessing master releases them. The rigors of the retreat provide participants with a prolonged and intensive encounter with their own failings in light of the values of compassion and equanimity that Fo Guang Shan promotes. And yet it is precisely through the planned encounter with failure that preceptees learn to cultivate themselves and thus to embody those values more successfully.

The retreat is realized as a radically set-apart, ritualized form of life- entered by participants explicitly so as to leave behind the specific relations, affections, attachments, and cares that ordinarily constitute their lives - to devote themselves to cultivation. In going beyond all that, it becomes transcendent in a sense. But it turns out that preceptees' labors in this realm are shaped and constrained by other social relations and by the fact that they are embodied beings. The ritualized life of a dedicated cultivator is, like ordinary life, a matter of standing, sitting, walking, sleeping, eating food, and rubbing along as one imperfect being together with many others. For a human being, there is no getting away from the human condition. The distinctiveness of the retreat and of monastic life 
in general turns out not to be a matter of kind; it differs from life outside the monastery only in the degree to which it facilitates cultivation. So, when participants return to lay life, ethical striving can and should continue, in the same way, but inevitably at a slower pace.

For Fo Guang Shan, the nonduality of the transcendent and the mundane is an inevitable condition of any activity (religious and ritualized or not) involving human beings. This is what makes Humanistic Buddhism humanistic: the perfection of the Buddhist path must be realized in the human world. It is this insight that, according to Master Hsingyun, lies at the heart of the Buddha's "original intent," one lost by centuries of Chinese monastic tradition, precisely because monks sought in vain to escape the conditions of human life so that they might cultivate, with the result that the laity came to believe that Buddhist teachings and practices were inaccessible to them while they were mired in the suffering of samsara.

In addition to casting doubt on the distinction between the ordinary and the transcendent, the retreat also gives us cause to question some other oppositions that anthropological thinking about ethical life has often taken to be universal or analytic. So, for example, contrary to the expectation that being in the flow of embodied, emotional, and intersubjective experience is opposed to self-consciousness and rational deliberation, the elicitation of powerful affective responses in the retreat goes hand in hand with the achievement of mindful detachment and cognitive transformation, and these are combined in the pursuit of ethical self-cultivation. Contrary to the common suggestion that self-cultivation is the self-regarding pursuit of monadic individuals and opposed to an ethics of care for the other, pursuit of ethical progress here is, in one sense, intrinsically individual — only you can do it for yourself - yet possible only as part of an intensely interactive shared collective life. And contrary to the idea that freedom and authority are at odds, the retreat is both a practice of and a method for strengthening the will, through voluntary subjection within hierarchical relations of power and discipline.

\section{ABSTRACT}

Fo Guang Shan (佛光山; Buddha's Light Mountain), an international Buddhist movement headquartered in Taiwan, regularly runs what it calls a short-term monastic cultivation retreat, a week-long residential program designed to provide lay members with an opportunity for intensive cultivation (修養; xiuyang or 修行; xiuxing). Contributions to the anthropology of ethics have recently drawn sharp distinctions between ordered, systematic ethics associated especially with religious traditions, and the compromise and accommodation that result from the exigencies of everyday life. This retreat, we argue, shows that the experience of ethical shortcomings can be a 
positive instrument and aspect of religious striving. While much debate in the anthropology of ethics assumes an a priori conceptual framework that opposes ordinary or everyday exigency to ordered transcendence, exigency and order in the Fo Guang Shan retreat are instead mutually constitutive and dynamically related. Here, failing and being corrected are not imperfections in, but central and ritually scripted elements of its ethical pedagogy. [ethics; self-cultivation; virtue; pedagogy; character; Buddhism; Taiwan; Fo Guang Shan]

\begin{abstract}
摘要
總部設於臺灣的佛光山是具有世界影響力的佛教組織。其各地道場 定期舉行之「短期出家修道會」活動通常持續一周, 旨在為信眾提供 密集修行機會。目前倫理人類學研究領域已明確區分了兩種道德實 踐: 其一為具有完美性和秩序性特質之系統, 如宗教; 其二為在日常 生活應對道德困境時形成的具有折哀性和適應性的倫理。本研究透 過分析佛光山「短期出家」活動, 提出：(1)「不圓滿」體驗在個人宗 教修行中具有獨特的積極促進作用; (2) 兩種倫理是相輔相成, 互 動共生的。在佛光山「短期出家」中, 活動參與者的行為錯誤與被矯 並非通常認為的「不圓滿」所在, 而是修行教育體系中至關重要的核 心部分。・[核心詞：道德; ・自修; - 美德; - 教學法; ・品格; - 佛教; 臺灣; 佛光山]
\end{abstract}

\title{
摘要
}

总部设于台湾的佛光山是具有世界影响力的佛教组织。其各地道场 定期举行“短期出家修道会”, 活动通常持续一周, 旨在为信众提供密 集修行机会。目前伦理人类学研究领域明确区分了两种道德实践：一 是具有完美性和秩序性特质的系统, 如宗教; 二是在日常生活应对道 德困境时形成的具有折衷性和适应性的伦理。本研究通过对佛光山“ 短期出家”活动的分析, 提出：(1) “不圆满”体验在个人宗教修行中具 有独特的积极促进作用; (2) 两种伦理是相辅相成, 动态共生的。在 佛光山“短期出家” 中, 活动参与者的失败感与被矫正经验并非通常认 为的“不圆满”所在, 而恰是修行教育体系中至关重要的核心部分。

-[核心词：道德; ・自修; ・美德; 教学法; ・品格; ・佛教; ・台湾;

- 佛光山]

\section{NOTES}

Acknowledgments We would like to express our gratitude to the Fo Guang Shan Buddhist organization for facilitating our research so generously in recent years. In the United Kingdom, we have been helped in countless ways, since the beginning of our project, by monastics and laypeople alike at the temples in London and Manchester, including Venerables Manchien, Miaoduo, Miaolung, and Miaoshiang. We owe thanks for the help received from the Fo Guang Shan leadership at Headquarters, near Kaohsiung in Taiwan, and from those in temples in France, Malaysia, Singapore, and Taiwan: Venerables Chuehcheng, Chuehpei, Chuehyuan, Huichuan, Ruching, Hsinbao, Huihao, Miaoguang, Miaojue, Miaoyue, Rusheng, Tzu- 
jong, Yilai, Yongguang, Zhiguan, and Zhiying. Thanks also to Miles Chen and Shi Baozhen for much practical help with fieldwork. We are extremely grateful for permission to participate in the retreats we attended in Taiwan and France, and we owe a particular debt to our guiding venerables during those retreats (Venerables Huiju, Huiren, and Huiyi) for their kindness and patience and for the explanations they provided to us on so many points. We are grateful, too, to all the venerables and other participants on those retreats and to the volunteers and donors whose support made those events possible. We conducted many long and exhaustive interviews with participants in past retreats in Taiwan, Singapore, Malaysia, and the United Kingdom. To all those who gave so much of their time, and who opened themselves so generously to our questions - sometimes no doubt impertinently probing, at others no doubt blindingly obvious - we are very grateful indeed. For permission to reproduce the photographs included here, we are grateful to Fo Guang Shan Life News Agency and Fo Guang Shan Tsung Lin University. Earlier versions of this essay were presented to seminars at the University of Kent and the Adam Mickiewicz University in Poznan, and we are grateful for insightful comments and questions. The following have read and commented on earlier drafts of the article, and we thank them again here for their various comments, criticisms, and suggestions: Peter Allen, Tom Bell, Matei Candea, Joanna Cook, Nicholas Evans, James Faubion, Paolo Heywood, Kai Lim, Patrick McKearney, Ni Haiying, Joel Robbins, Shi Baozhen, and Di Wu. We express our gratitude also to the editors of Cultural Anthropology, Brad Weiss, Heather Paxson, and Christopher Nelson, for what we have experienced as a remarkably supportive, insightful, and efficient editorial process, and to the three anonymous reviewers who read this article for the journal. For financial support for the research that informs the essay, we are grateful for a British Academy/ Leverhulme Trust Grant (SG151876). As ever, responsibility for errors and omissions resides with the authors.

1. In Taiwan in 2016, this took the form of an "education fee" of NTD 500 (US\$16), with a note that an accommodation and food fee of NTD 1000 (US\$32) had already been covered by donors. In Paris in 2018, the fees amounted to $€ 120$ (US\$137) for nonmembers, $€ 100$ (US\$114) for members, and $€ 80$ (US\$91) for students.

2. Elsewhere, the framework in Robbins's approach is provided by roughly congruent oppositions between routine necessity and freedom of choice (Robbins 2007) or between perfectly realized and conflicting values (Robbins 2018).

\section{REFERENCES}

Asad, Talal

1993 Genealogies of Religion: Discipline and Reasons of Power in Christianity and Islam. Baltimore, Md.: Johns Hopkins University Press.

Beekers, Daan, and David Kloos, eds.

2018 Straying from the Straight Path: How Senses of Failure Invigorate Lived Religion. New York: Berghahn.

Borneman, John

2015 Cruel Attachments: The Ritual Rehab of Child Molesters in Germany. Chicago: Chandler, Stuart University of Chicago Press.

2004 Establishing a Pure Land on Earth: The Foguang Shan Perspective on Modernization and Globalization. Honolulu: University of Hawai'i Press.

Cheng, Yinghong

2009 Creating the "New Man": From Enlightenment Ideals to Socialist Realities. Honolulu: Clarke, Morgan University of Hawai'i Press.

2014 "Cough Sweets and Angels: The Ordinary Ethics of the Extraordinary in Sufi Practice in Lebanon." Journal of the Royal Anthropological Institute 20, no. 3: 407425. https://doi.org/10.1111/1467-9655.12117. 
Cook, Joanna

2010 Meditation in Modern Buddhism: Renunciation and Change in Thai Monastic Life. New York: Cambridge University Press.

Das, Veena

2010 "Engaging the Life of the Other: Love and Everyday Life." In Ordinary Ethics: Anthropology, Language, and Action, edited by Michael Lambek, 376-99. New York: Fordham University Press.

2012 “Ordinary Ethics." In A Companion to Moral Anthropology, edited by Didier Fassin, 133-49. Malden, Mass.: Wiley-Blackwell.

Emmet, Dorothy

1994 The Role of the Unrealisable: A Study in Regulative Ideals. London: St. Martin's Press.

Fahy, John

2017 "Failing Well: Accommodating Vices in an Ideal Vedic City." HAU 7, no. 2: 331-50. https://doi.org/10.14318/hau7.2.030.

Faubion, James D.

2011 An Anthropology of Ethics. New York: Cambridge University Press.

2013 "The Subject That Is Not One: On the Ethics of Mysticism." Anthropological Theory 13, no. 4: 287-307. https://doi.org/10.1177/1463499613509991.

Fo Guang Shan

n.d. 佛教叢書7一儀制 [Fojiao congshu 7-yizhi; Fo Guang Shan Encyclopedia, 7].

Fo Guang Shan Monastery Worldwide Web. Accessed August 8, 2018. https:// www.fgs.org.tw/fgs_book/fgs_frbook.aspx.

Foucault, Michel

1997 Ethics, Subjectivity, and Truth: Essential Works of Michel Foucault, 1954-1980, Volume 1. Edited by Paul Rabinow. New York: New Press.

Harding, Susan

1991 "Representing Fundamentalism: The Problem of the Repugnant Cultural Other."

Social Text 58, no. 2: 373-93. https://www.jstor.org/stable/40970650.

Hirschkind, Charles

2006 The Ethical Soundscape: Cassette Sermons and Islamic Counterpublics. New York: Columbia University Press.

Hsingyun, Venerable Master

2016 Humanistic Buddhism: Holding True to the Original Intents of the Buddha. Kaohsiung, Taiwan: Fo Guang Shan Cultural Enterprises.

Huang, C. Julia

2009 Charisma and Compassion: Cheng Yen and the Buddhist Tzu Chi Movement.

Cambridge, Mass.: Harvard University Press.

Humphrey, Caroline, and James Laidlaw

1994 The Archetypal Actions of Ritual: A Theory of Ritual Illustrated by the Jain Rite of Worship. New York: Oxford University Press.

Ivanhoe, Philip J.

2000 Confucian Moral Self Cultivation. 2nd ed. Indianapolis, Ind.: Hackett.

Jackson, Michael

2013 The Wherewithal of Life: Ethics, Migration, and the Question of Well-Being. Berkeley: University of California Press.

Jones, Charles Brewer

1999 Buddhism in Taiwan: Religion and the State, 1660-1990. Honolulu: University of Hawai'i Press.

Keane, Webb

2016 Ethical Life: Its Natural and Social Histories. Princeton, N.J.: Princeton University Press.

Kipnis, Andrew

2006 "Suzhi: A Keyword Approach." China Quarterly 186: 295-313. https://doi. org/10.1017/S0305741006000166. 
Kondo, Dorinne K.

1987 "Creating an Ideal Self: Theories of Selfhood and Pedagogy at a Japanese Ethics Kuo, Cheng-Tian

Retreat." Ethos 15, no. 3: 241-72. https://doi.org/10.1525/eth.1987.15.3.02a00010.

2008 Religion and Democracy in Taiwan. Albany: State University of New York Press.

Laidlaw, James

1995 Riches and Renunciation: Religion, Economy, and Society among the Jains. Oxford: Clarendon Press.

2002 "For an Anthropology of Ethics and Freedom." Journal of the Royal Anthropological Institute 8, no. 2: 311-32. https://doi.org/10.1111/1467-9655.00110.

2014 The Subject of Virtue: An Anthropology of Ethics and Freedom. New York: Cambridge University Press.

Lambek, Michael

2010 "Introduction." In Ordinary Ethics: Anthropology, Language, and Action, edited by Michael Lambek, 1-37. New York: Fordham University Press.

Lempert, Michael

2013 "No Ordinary Ethics." Anthropological Theory 13, no. 4: 370-93. https://doi. org/10.1177/1463499613505571.

Lester, Rebecca J.

2005 Jesus in Our Wombs: Embodying Modernity in a Mexican Convent. Berkeley: University of California Press.

Lynteris, Christos

2013 The Spirit of Selflessness in Maoist China: Socialist Medicine of the New Man. New York: Palgrave Macmillan.

Madsen, Richard

2007 Democracy's Dharma: Religious Renaissance and Political Development in Taiwan. Berkeley: University of California Press.

Mahmood, Saba

2005 Politics of Piety: The Islamic Revival and the Feminist Subject. Princeton, N.J.: Princeton University Press.

Mair, Jonathan

2014 "Fo Guang Shan Buddhism and Ethical Conversations across Borders: 'Sowing Seeds of Affinity." COLLeGIUM, no. 15: 66-89. http://hdl.handle.net/10138/45244.

Marsden, Magnus

2005 Living Islam: Muslim Religious Experience in Pakistan's North-West Frontier. New York: Cambridge University Press.

Mattingly, Cheryl

2012 "Two Virtue Ethics and the Anthropology of Morality." Anthropological Theory 12, no. 2: 161-84. https://doi.org/10.1177/1463499612455284.

Mayblin, Maya, and Diego Malara

2018 "Introduction: Lenience in Systems of Religious Meaning and Practice." Social Analysis 62, no. 3: 1-20. https://doi.org/10.3167/sa.2018.620301.

Mittermaier, Amira

2012 "Dreams from Elsewhere: Muslim Subjectivities beyond the Trope of SelfCultivation." Journal of the Royal Anthropological Institute 18, no. 2: 247-65. https://

Robbins, Joel doi.org/10.1111/j.1467-9655.2012.01742.x.

2004 Becoming Sinners: Christianity and Moral Torment in a Papua New Guinea Society. Berkeley: University of California Press.

2007 "Between Reproduction and Freedom: Morality, Value, and Radical Cultural Change." Ethnos 72, no. 3: 293-314. https://doi.org/10.1080/00141840701576919.

2015 "Ritual, Value, and Example: On the Perfection of Cultural Representations." Journal of the Royal Anthropological Institute 21, S1: 18-29. https://doi. org/10.1111/1467-9655.12163. 
2016 "What Is the Matter with Transcendence? On the Place of Religion in the New Anthropology of Ethics." Journal of the Royal Anthropological Institute 22, no. 4: 767-81. https://doi.org/10.1111/1467-9655.12494.

2018 "Where in the World Are Values? Exemplarity, Morality, and Social Process." In Recovering the Human Subject: Freedom, Creativity, and Decision, edited by Schielke, Samuli James Laidlaw, Barbara Bodenhorn, and Martin Holbraad, 174-92. New York: Cambridge University Press.

2009 "Being Good in Ramadan: Ambivalence, Fragmentation, and the Moral Self in the Lives of Young Egyptians." Journal of the Royal Anthropological Institute 15, S1: S24-40. https://doi.org/10.1111/j.1467-9655.2009.01540.x.

2015 Egypt in the Future Tense: Hope, Frustration and Ambivalence, before and after 2011. Bloomington: Indiana University Press.

Schielke, Samuli, and Liza Debevec, eds.

2012 Ordinary Lives and Grand Schemes: An Anthropology of Everyday Religion. New York: Berghahn.

Seligman, Adam B., Robert P. Weller, Michael J. Puett, and Bennett Simon

2008 Ritual and Its Consequences: An Essay on the Limits of Sincerity. New York: Oxford University Press.

Simon, Gregory

2009 "A Soul Freed of Cares? Islamic Prayer, Subjectivity, and the Contradictions of Moral Selfhood in Minangkabau." American Ethnologist 36, no. 2: 258-75. https:// doi.org/10.1111/j.1548-1425.2009.01134.x.

Singh, Bhrigupati

2015 Poverty and the Quest for Life: Spiritual and Material Striving in Rural India. Chicago: University of Chicago Press.

Smith, Adam

1976 The Theory of Moral Sentiments. Edited by D. D. Rafael and A. L. Macfie. New York: Oxford University Press. Originally published in 1790.

Williams, Bernard

1985 Ethics and the Limits of Philosophy. Cambridge, Mass.: Harvard University Press. Yao, Yu-Shuang, and Richard Gombrich

2017 "Christianity as Model and Analogue in the Formation of the 'Humanistic' Buddhism of Tài Xū and Hsīng Yún.” Buddhist Studies Review 34, no. 2: 205-237.

Zigon, Jarrett https://doi.org/10.1558/bsrv.35392.

2011 "HIV Is God's Blessing": Rehabilitating Morality in Neoliberal Russia. Princeton, N.J.: Princeton University Press. 